See discussions, stats, and author profiles for this publication at: https://www.researchgate.net/publication/300086035

'These people protesting might not be so strident if their own jobs were on the line: Representations of the 'economic consequences of opposition to the Iraq war in the Irish natio...

Article in Media War \& Conflict · April 2016

DOI: $10.1177 / 1750635216637635$

5 authors, including:

33 PUBLICATIONS 43 CITATIONS

SEE PROFILE 
'These people protesting might not be so strident if their own jobs were on the line': Representations of the 'economic consequences' of opposition to the Iraq war in the Irish national press
Media, War \& Conflict

I-24

(C) The Author(s) 2016

Reprints and permissions: sagepub.co.uk/journalsPermissions.nav DOI: $10.1177 / 1750635216637635$ mwc.sagepub.com

\title{
Colin Coulter
}

Department of Sociology, Maynooth University, Ireland

\section{Harry Browne}

School of Media, Dublin Institute of Technology, Ireland

\section{Roddy Flynn}

School of Communications, Dublin City University, Ireland

\section{Vanessa Hetherington}

Independent Scholar, Dublin, Ireland

\section{Gavan Titley}

Centre for Media Studies, Maynooth University, Ireland

\begin{abstract}
In this article, the authors examine the ways in which the social movement in Ireland opposed to the Iraq war was represented in the national press. The article draws upon data generated by the largest research project of its type ever conducted in an Irish context. The authors considered representations of the anti-war movement in II daily and Sunday newspapers over a period of 9
\end{abstract}

\section{Corresponding author:}

Colin Coulter, Department of Sociology, National University of Ireland, Maynooth, County Kildare, Ireland. Email: colin.coulter@nuim.ie 
months. One of the principal threads that ran through newspaper coverage of the time centred upon concerns about the possible 'economic consequences' of opposing the war against Iraq. A close reading of the data reveals that the familiar reliance of journalists on official sources and interpretations ensured that the national press tended to cast the anti-war movement in Ireland as a danger to both the regional and national economy at a time of seemingly unprecedented prosperity.

\section{Keywords}

anti-war movement, Iraq war, Ireland, political economy, press coverage, US corporations

\section{Introduction}

In the opening weeks of 2003, political debate across the globe was dominated by the imminent and seemingly inevitable invasion of Iraq by a 'coalition of the willing' led by the United States. Those powerful figures in Washington that sought to install the 'new American century' found their quest for hegemony increasingly challenged by the emergence of what The New York Times (Tyler, 2003) termed 'the second superpower' in the guise of 'world public opinion'. The scale of opposition to the forthcoming war was made starkly apparent on a day of worldwide demonstrations that had been agreed at the European Social Forum in Florence the previous November (Gillan et al., 2008: 113). On 15 February 2003 (or 'F15' as it became in activist shorthand), 'over 10 million people' (Seppälä, 2012: 1) marched in 'at least 800 cities' (Nineham, 2013: 29) in what was 'the most global protest in history' (Gillan et al., 2008: 113). The unprecedented size and truly worldwide nature of the movement against the Iraq war lend it a special and enduring significance (Barbrook, 2007: 288; Seppälä, 2012). This has rarely been acknowledged, however, in the academic studies of media coverage of the period. There have of course been a host of valuable studies of how journalists reported the Iraq war published over the last decade (Carruthers, 2011; Miller, 2004; Mirzoeff, 2005; Tumber and Palmer, 2004). In the main, however, these have failed to provide focused or sustained accounts of how the anti-war movement was mediated. Indeed, perhaps the sole exception to this rule is to be found in the work of Robinson et al. (2010) who provide a sustained and finely detailed analysis of how dissenting voices against the conflict were depicted in the British print and broadcast media.

In view of the scale of the protests summoned by the invasion of Iraq, it is quite remarkable that there have not been many more accounts of how the mainstream media sought to depict the anti-war movement. This article represents in part an attempt to redress this glaring absence in the academic literature. The research that the article draws upon documents media processes that played out in a very specific national context. While the Irish Republic remains in principle a 'neutral' country, it did in fact make quite a substantial material contribution to the drive to war against Iraq. The passage of tens of thousands of American troops en route to the Persian Gulf through a small civilian airport in the west of Ireland ensured that the country would have an especially large and vibrant anti-war movement. The research that we set out below, therefore, not only provides one of the few sustained accounts of how the media sought to deal with the 
competing political interests associated with the invasion of Iraq but also offers the only examination to date of how these processes unfolded in the specific context of what was, in spite of appearances to the contrary, a significant strategic site in the 'war on terror'.

The project that gave rise to this article examined a wide range of ways in which the Irish national press sought to represent the emergence of a mass movement opposed to the invasion of Iraq. One of the more substantial debates that was played out in the print media centred on the potential 'economic consequences' for Ireland if it were to oppose this latest installment of the 'war on terror'. The discussions of the political economy of war that featured heavily in the Irish press have perhaps a significance that transcends this specific national context. The response of the print media to the emergence of an increasingly substantial and vibrant anti-war movement in Ireland varied enormously across publications and over time. While Irish newspapers were in the main deeply sympathetic to the enormous demonstration that filled central Dublin on 15 February 2003, the press tended to respond with universal hostility to more radical forms of protest and in particular to those that might offend the sensitivities of American corporate interests and, therefore, have 'economic consequences'. The preoccupation of the Irish print media with the political economy of opposing the Iraq war might be held to reveal its position within a broader network of political and economic interests both indigenous and external to Ireland. Without perhaps even meaning to, the anti-war movement posed certain searching questions of the model of national development that had been pursued in Ireland over the previous generation. In more specific terms, in casting light on the growing political subservience of the country to American interests, protestors threatened to draw greater attention to its deepening economic dependence. The challenge that the anti-war movement had come to represent to the dominant interests that drove the 'Celtic Tiger' was inevitably met with a chorus of powerful voices - political, corporate, media - that was channelled through the endeavours of the national press to depict peace protestors as willful egotists intent on banishing the first era of prosperity the country had ever known. In these debates, therefore, we come to see rather more clearly than usual the very specific constellation of material and figurative power that defines the social world not only in Ireland but elsewhere.

\section{The Irish context}

In his reflections on the carnage in the Persian Gulf, Slavoj Žižek (2005: 8) suggests that when, in the midst of the passions and controversies of the period, people spoke about Iraq they were, in fact, really talking about something, or somewhere, else entirely. The kernel of sense at the heart of this characteristically counter intuitive argument becomes readily apparent when we begin to examine the ways in which the debate about the Iraq war played out in an Irish context. On 22 March 2003 - 48 hours after hostilities had begun - the Evening Herald sought to gauge popular opinion on the invasion of Iraq among pedestrians in Dublin city centre. The most striking aspect of the various testimonies that featured in the 'vox pop' conducted by the tabloid newspaper was that, while there were abundant references to the United States, the proper noun 'Iraq' did not appear even once. It would seem then that when Irish people spoke about the Iraq war - even at a time when the debate about, and images of, the US led invasion were virtually 
inescapable - they were perhaps really talking about matters that had very little indeed to do with the Persian Gulf.

It often appeared that the advent of the 'war on terror' had initiated a prolonged and, at times, heated national conversation about the nature of Ireland's relationship with the United States (Little, 2004). Traditionally, there have of course been strong cultural and familial connections between the two countries, with around 40 million Americans making claim to some version of Irish antecedence. Over the last two decades, these abiding affective ties have been mirrored in an increasingly substantial economic association between Ireland and the United States. The end of the Cold War heralded an enormous wave of multinational capital, originating primarily in the United States, roving the globe in pursuit of fresh markets and enhanced profits (Henwood, 2005). In a European context, the principal beneficiary of this new generation of footloose capital was the Irish Republic. In per capita terms, Ireland received more new foreign direct investment than any other member state of the European Union, attracting three times more than its nearest competitor, the Netherlands (Smith, 2005: 38). Throughout the 1990s, the number of American multinationals operating in the Irish Republic grew exponentially and by the end of the decade two thirds of all investment in the country would owe its origins to the United States (O'Hearn, 2003: 39). This influx of transnational capital was widely held to have been instrumental in sparking a period of seeming prosperity that was invariably designated by the metaphor of the 'Celtic Tiger'. As the century turned, the Irish Republic was recording rates of economic growth that had no equivalent in the western world. One eminent historian sought to capture the reversal in Ireland's material fortunes by suggesting that the erstwhile 'carthorse' had become a 'thoroughbred' (Lee, 1996). The scale of the transformation was offered more literal expression in the official statistics of the body that represents the interests of the world's richest countries. In 2003, as the principal military power in the world prepared to wage war against impoverished Iraq, the Organisation for Economic Co-operation and Development (OECD) reported that in terms of GDP per capita the Irish Republic had become the fourth wealthiest state in the world (Coulter, 2015: 4-5; Kuhling and Keohane, 2007: 1; Ó Riain, 2014: 34-35; Smith, 2005: 38). ${ }^{1}$

The contribution that multinational capital had made to Ireland's newfound national prosperity featured prominently in official discourse during the era of the Celtic Tiger. Key figures in the Irish political establishment were often at pains to underline that the investment and expertise of American corporations had allowed the Irish Republic to transcend its former, seemingly perennial status of economic underdevelopment and to become 'a shining light and a beacon' to other small countries in pursuit of prosperity (MacSharry and White, 2000: 360). While this was certainly the hegemonic narrative of the Celtic Tiger period, there also existed another, more critical but much less prevalent, reading of the course that Ireland was following (Coulter, 2003a). During the long years of the economic boom, there was a gnawing sense among some elements of Irish society that the growing economic dependence upon the United States had given rise to a particularly iniquitous form of political dependence as well (Devine, 2006; Tonra, 2006: 181-196). While this particular source of unease remained largely latent when the widely revered figure of Bill Clinton was in the White House, it would become ever more prevalent and vocal when his widely unpopular successor assumed office. As the Bush administration escalated its plans to invade Iraq in the face of widespread international 
opposition, events in a small town in the west of Ireland would act as a lightning rod for the growing anxiety that the price of economic prosperity had been paid in the coin of national sovereignty.

The landing strip outside Shannon represents the first landfall for flights crossing the Atlantic, giving the facility a geopolitical significance that belies its status as a small regional airport. Over the course of several decades, troops from the United States and elsewhere have passed through the County Clare town on their way to bases and theatres of conflict rather further afield. From the autumn of 2002, peace activists monitoring the airport began reporting an escalation in the already substantial volume of American military personnel and cargo arriving in Shannon. In the 15 months that preceded the invasion of Iraq, there were more than 100,000 journeys through the facility by US troops, with almost 35,000 of these in the 11 weeks alone that preceded the onset of hostilities (Allen and Coulter, 2003: 8-9; Doris, 2007: 6). As reports and images of American soldiers passing time in Shannon airport began to circulate, the effective colonization by a foreign military of an ostensibly civilian airport became for some the most damning evidence that Ireland's economic advances had come at the expense of its supposedly 'traditional' status as a 'neutral' state.

While the notion of neutrality has a profound resonance within Irish political culture, it remains a nebulous concept, meaning different, and often incompatible, things to different political constituencies (Tonra, 2006: 153-180). The ideal of a 'neutral' Ireland is held dear by a spectrum of opinion that features advocates of something close to absolute political autarky at one pole and champions of participation in the nascent military structures of an enlarged Europe at the other. Between these is the most prevalent position on 'neutrality' that insists that Ireland should only participate in military operations that are sanctioned by the 'surrogate' (p. 180) of a United Nations mandate. The events that were unfolding both at Shannon and at the level of 'the international community' (Badiou, 2006: 42) had the effect of blurring many of these political distinctions, allowing those who often differed in their understanding of neutrality to find common cause. Those American troops who were stopping off on Irish soil were, after all, on their way to take part in a war that lacked the approval of the United Nations Security Council and hence was almost certainly in breach of international law. Against this backdrop, even those possessed of the least dogmatic understanding of what Irish foreign policy should be were likely to see events at Shannon airport as an infringement of the country's neutrality.

The growing sense of anger nurtured by events at Shannon would be a pivotal factor in producing one of the largest social movements that Ireland has ever seen. As was the case elsewhere, the anti-war movement that emerged in an Irish context was 'an uneasy alliance of remarkably diverse groups and individuals' (Gillan et al., 2008: 73). The most prominent organisation within this 'movement of movements' was the Irish Anti War Movement (IAWM), formed at a public meeting in Dublin two weeks after the atrocities that occurred in the United States on 11 September 2001. Like its analogue in the United Kingdom, the Stop the War Coalition (StWC) (Gillan et al., 2008: 2, 83; Sinclair, 2013), the IAWM was, and remains, essentially controlled by the Socialist Workers Party (Browne, 2008: 47) but was nonetheless keen to build as broad a coalition of anti-war forces as possible. The organisation incorporated a range of political groupings on its steering committee and collaborated with other bodies such as the Peace and Neutrality 
Alliance (PANA), which has particularly close ties to the Irish Labour Party, and the NGO Peace Alliance, which articulates a range of voices from Irish civil society. These three groupings co-operated in organising the largest demonstration that Ireland had seen in a generation on 15 February 2003. While PANA and the NGO Peace Alliance were scheduled as co-sponsors of the event, it was the energy and personnel of the IAWM that were principally responsible for drawing more than 100,000 people onto the streets of Dublin on that cloudless early spring day.

The principal line of division within the 'unity of opposites' that was the anti war movement in Ireland was one familiar from other times and places (Gitlin, 1980: 58), reflecting divergent attitudes towards '(non violent) direct action'. The three organisations mentioned above essentially represented the 'respectable' face of anti-war opinion and tended to frown upon more radical forms of protest. Both PANA and the NGO Peace Alliance refused to envisage supporting 'direct action' in all circumstances for fear of association with anything that might be deemed 'violent'. The IAWM adopted a somewhat more pragmatic position akin to that of its sister organisation in Britain, the StWC (Seppälä, 2012: 109, 142), and at times indicated a willingness to participate in more radical protests so long as they had a 'mass' character. Incidents of direct action by individuals or small groups, however, were typically dismissed as 'divisive' acts that endangered the building of the wide constituency of support deemed necessary to wield meaningful political influence.

While the mainstream of the anti-war opinion in Ireland was strenuously opposed to direct action, there were other elements within the movement that held to a rather different viewpoint. In numerical terms, the most substantial of these was the Grassroots Network Against War (GNAW), a coalition of anarchists that included members of the Workers' Solidarity Movement. It was GNAW that called for people to come to Shannon airport on 1 March 2003 to tear down the perimeter fence and occupy the facility, a controversial moment that we will return to later. Those elements of the anti-war movement supportive of direct action also included a number of smaller groupings as well as individuals. On three separate occasions, activists expressed their opposition to what was happening in Shannon by targeting American military hardware located in the airport. On 4 September 2002, Eoin Dubsky painted the slogan 'No War' on a Hercules plane; on 28 January 2003, Mary Kelly took a hatchet to the nose of a US Navy aircraft; and on 3 February 2003, five individuals operating within the 'Catholic Worker' tradition adopted the name 'the Pitstop Ploughshares' before inflicting more damage on the same Navy plane (Browne, 2008). These last two actions in particular would become the source of considerable consternation within and beyond the political establishment and, as we shall see later, were to have a great deal of bearing on mainstream political debate in Ireland as the prospect of the Iraq war loomed ever closer.

The emergence of an increasingly large and vibrant anti-war movement in Ireland posed considerable difficulties for the coalition government of the day, or at least for its principal constituent. The junior partners in government at the time were the now disbanded Progressive Democrats (PDs), a small 'kingmaker' party whose aggressively neoliberal agenda rendered them, in the words of their leader Mary Harney, rather closer to 'Boston' than to 'Berlin' (White, 2011). The expressly 'Anglo-American' politics (Tonra, 2006) of the PDs meant that the prospect of a war in Iraq posed few real dilemmas for 
them. It was always entirely inevitable that the party would offer unequivocal support for the invasion and in the weeks that preceded the onset of hostilities it was senior Progressive Democrats who would be most explicitly vehement among those who sought to denounce and deride the anti-war movement in Ireland. The position in which the more senior partner in government found itself was, in contrast, altogether more precarious.

The electoral appeal of Fianna Fáil had traditionally rested not least upon its insistence that Ireland exist as a sovereign and independent state. While the most successful political party in Irish history had moved sharply towards neoliberal economic policies in recent times, its politics remained defined in part by a version of populist nationalism signified in its claim to be 'the Republican party'. The Republican credentials of Fianna Fáil were, however, at risk of being tarnished by the ongoing use of an Irish airport by a foreign military power that was happening on its watch. The hierarchy of the party would have been keenly aware both that opinion polls were finding that most Irish people were opposed to the US military using Shannon airport and to the prospective war against Iraq and that these majorities would have included large numbers of their own supporters (Irish Political Studies, 2005: 52-56; Miller, 2005: 168-169). This realisation effectively ensured that Fianna Fáil had relatively little room for manoeuvre. On the one hand, the senior party of government could not afford to be seen to simply dismiss the demands of the anti-war movement for fear of electoral reprisals. On the other, it was loathe to make concessions to the anti-war lobby for fear that it might endanger the political and economic benefits deemed to have flown from accommodating Washington's interests. Inevitably, Fianna Fáil sought to square the circle of these incompatible ideological interests by resorting to the evasions and equivocations that were the signature of An Taoiseach (Prime Minister) Bertie Ahern's period in office (Browne, 2008: 88). Although senior figures in the Irish government would repeatedly state their hope that the crisis over Iraq would be resolved in a manner that both secured peace and respected the authority of the UN, all the while they were preparing the ground to facilitate the United States in its drive towards a war of questionable legality that would threaten the authority of the UN (Rees, 2004).

The prospect and advent of the Iraq war, therefore, summoned passions and divided opinion in Ireland as much as in most other countries. Although the Irish Republic was not a direct participant in the 'coalition of the willing', developments at Shannon airport ensured that debates in the state often had a particularly sharp edge and a distinctly national flavour (Coulter, 2003b). Before examining how these debates were played out through the medium of the national press, we will outline briefly the original primary data upon which the discussion that follows will draw.

\section{The composition of the research}

This article arises out of one of the most substantial research projects concerned with media coverage of social movements ever conducted in an Irish context. We set out to consider how protests and protestors against the Iraq war were represented in the national press. In total, 11 Daily and Sunday newspapers were consulted, namely the Daily Star, Evening Herald, Irish Examiner, Irish Independent, Irish Times, Ireland on Sunday, Sunday Business Post, Sunday Independent, Sunday Times, Sunday Tribune and Sunday 
World. ${ }^{2}$ Our principal concern was to examine how the anti-war movement was depicted in what was offered as 'hard news' rather than subjective commentary. Hence, we included front page stories, home and world news, but not editorials, letters and opinion pieces. While the articles that we chose to consider were meant to represent the 'objective' reportage supposedly on offer in the 'news' sections of the 11 publications, it would transpire that some of the pieces that we examined would, as we will illustrate in due course, bear more than a passing resemblance to the kinds of polemic more commonly associated with the 'opinion' columns.

It was intended that the research would offer a sense of how media coverage evolved over that broad arc of time in which the Iraq war moved from being a possibility that consumed and divided world opinion to being a gruesome reality that continued to consume and divide world opinion. Accordingly, we examined the Irish newspapers we had selected over a period of 9 months. The beginning of our time frame was 1 September 2002 and hence the research captured the escalation of the Iraq crisis that autumn, incorporating the first incidence of 'direct action' against US military hardware at Shannon airport and the publication of the 'sexed up' dossier that the Blair administration hoped would persuade the British public of the case for war (Robinson et al., 2010: 71-72). The final newspaper editions we consulted appeared on 31 May 2003 and therefore the scope of the project took in key events such as the declaration of 'mission accomplished' by President Bush and the subsequent disclosure by senior members of his administration of the actual, rather less than altruistic, reasons for the invasion of Iraq (Tumber and Palmer, 2004: 126).

Each of the newspapers was read by the same member of the research team either in hard copy or on microfiche in the archives of the National Library in central Dublin.

This painstaking work revealed a total of 505 articles that were concerned, in whole or in part, with the anti-war movement in Ireland. The significance of stories dealing with groups opposed to the Iraq war was reflected both in the sheer volume of articles, amounting to some 5,344 paragraphs in total, and in their location within the newspapers analysed. Articles devoted to the anti-war movement appeared on 44 front pages, with 111 appearing in the first three pages, 159 in the first five pages and 245 in the first seven pages. Each of these stories was photocopied, scanned and saved as a permanent document format file for future reference. Individual articles were assigned an identification number and examined more closely to document the newspaper in which it appeared, the author(s), the initiating source(s), the page that it appeared on, the location it occupied within that page, the composition and sources of the headline, the length of the piece and so forth. All of the data was stored on an Access database, allowing the researchers to carry out finely detailed examination of the information as well as to conduct broader analysis of the relationships between a host of variables. An early stage of the project, a close reading of the stories already gathered suggested that there were five principal themes that might guide the analysis of the considerable volume of information being generated, namely: the motivations ascribed by the media to protestors, the language employed to describe them, the motivations ascribed to the anti-war movement by official sources, the implications of violence associated with the protests and the economic consequences of resisting the American drive towards war. All of the existing and subsequent newspaper articles were coded in terms of whether or not they touched upon these 
main threads running through the data. While the first four themes identified above will be explored elsewhere, this particular article is concerned solely with the final one, that is, with the debates that for a time raged in Ireland about the potential economic consequences of resisting the American drive to war against Iraq.

The discussion of the political economy of the anti-war movement in Ireland that follows draws upon a substantial body of both quantitative and qualitative primary data. The finely detailed information garnered during the project allows us to discern numerical patterns in how Irish newspapers reported the controversies that attended the Iraq war. In particular, these data ensure that we are able to map out how press coverage unfolded over time and to identify the moments when discussion of the "economic consequences' of peace activism became especially intense. This numerical information offers a broad context in which we turn to look more closely at what precisely the newspapers said at the time. In part, the evidence offered below entails a sequence of quotations from journalists assigned to cover the heated debates that were sparked by the Irish government's seeming equivocation over the prospect of war against Iraq. It is customary when advancing qualitative data of this kind to offer certain qualifications that they should be taken to be 'indicative' rather than 'representative'. In this specific context, however, provisos of this kind are perhaps unnecessary. The very considerable data generated by this research project reveal that there were often very substantial variations in how different newspapers approached the anti-war movement. These distinctions tended to disappear, however, when the Irish press came to consider the official assertion that opposing the Iraq war would have severe 'economic consequences'. The quotations that are employed below to illustrate the media coverage of the day might be said then to be genuinely representative. Each could have been replaced by several other similar accounts from several other newspapers.

\section{The political economy of opposing the Iraq war}

One of the principal controversies that dominated Irish public debate in the era of the Iraq crisis centred on the potential consequences that opposing Washington might have for the newfound seeming prosperity of the nation. In the 9-month period that we examined, almost one fifth of the stories (99 out of a total of 505) concerned with the anti-war movement had an explicitly 'economic dimension'. These articles were not spread evenly over time but were, significantly, concentrated heavily in what was the most critical moment in the prolonged debate over Iraq, when the balance of forces on either side the argument was most finely poised and there still seemed at least a possibility that war might be averted. Two thirds (67 of 99) of all of the publications dealing with economic themes appeared in a 5-week span between late January and early March 2003. If we look more closely still at this particular period of ever more frenetic political debate and activism, another even more specific and very telling pattern becomes apparent.

It would appear the issue of the fate of the Irish economy moved to the centre of a debate that was ostensibly concerned with the plight of Iraq precisely at those moments when elements of the anti-war movement transgressed what the political establishment designated as the permissible boundaries of protest - or, in other words, when they moved beyond what Hallin (1986) has termed the sphere of 'legitimate controversy'. 
Over the course of the research, there were three clear spikes in stories concerned with the economic consequences of opposing the war and these coincided with the three actual or proposed incidents of direct action at Shannon airport that occurred when the debate over Iraq was at its height. There were 14 stories with an 'economic' dimension in the week after Mary Kelly damaged the nose of the US Navy plane on 28 January; 22 in the week that followed the attempts of the 'Pitstop Ploughshares' on 3 February to decommission the same aircraft; and 16 in the week either side of the 1 March demonstration called by the Grassroots Network Against War that aimed to facilitate a mass incursion at the facility. In other words, more than half (52 of 99) of all the articles considering the economic repercussions of anti-war activism that appeared over a frame of 42 weeks were clustered in just 3 weeks that adjoined three separate moments of direct action. Each time that activists sought to move beyond the prescribed parameters of 'respectable' protest, official sources prompted a rash of pieces in the newspapers speculating on what snubbing the political wishes of Washington might mean for the health of the Celtic Tiger. While it may have been the actions of elements within the anti-war movement that, inadvertently, brought economic matters into the political controversies that attended the Iraq crisis, it would be other, rather more powerful, voices that would dominate these discussions.

It has been documented in a wealth of research that the mainstream media invite their audience to understand radical social movements in particular ways by placing them within specific frames of meaning (Dimitrova and Strömbäck, 2008). According to Entman (1993: 56), to 'frame' is 'to select some aspects of a perceived reality and make them more salient in communicating context, in such a way as to promote a particular problem definition, causal interpretation, moral evaluation, and/or treatment recommendation'. Research conducted over the last four decades suggests that journalists have with considerable regularity sought to trivialise, marginalise and even demonise radical forms of social protest (Adler and Mitelman, 2004; Gitlin, 1980: 27-28; Halloran et al., 1970; McLeod and Detenber, 1999). Indeed, the hostility of the conventional media toward social movements has been sufficiently prevalent and recurrent that Chan and Lee (1984) have suggested that it represents a 'protest paradigm'. One of the media practices that is most recognisably paradigmatic is the propensity of journalists to foreground the opinions and interests of the political establishment (Dittmer and Parr, 2011; Robinson et al., 2010: 152-158; Tumber and Palmer, 2004: 103). In part, this pattern emerges out of journalistic routines, as reporters seek to cultivate official figures that can provide quick and reliable access to information. The tendency for journalists to draw primarily upon 'official sources' was borne out strongly in the research that we conducted. In those articles that dealt with the political economy of the anti-war movement, it was representatives of the Irish state who were allowed to speak most often and at most length. Within these stories, official figures such as politicians and their spokespersons, Gardai (police officers) and representatives of the statutory airport authority at the time Aer Rianta were three times more likely than anti-war activists to have been the initiating sources ( 77 vs 25 ); four times more likely to have been quoted directly (43 vs 10); three times more likely to have initiated headlines (23 vs 8); and four times more likely to have been quoted in headlines (8 vs 2). 
These data suggest that in the prolonged and often heated debates initiated by the Iraq crisis and played out in the national media, the Irish political establishment was allocated considerably more speaking time. The reliance of Irish journalists on official sources would inevitably prove to be both symptom and cause of the manner in which they would seek to 'frame' the anti-war movement. Key players within the coalition government were keen to promulgate the view that the anti-war movement amounted to little more than reckless egoists whose actions threatened economic ruin at both regional and national level. If we return to the newspapers published during the period, it becomes quickly apparent that the national press frequently invited their readers to perceive the anti-war movement through this specific, pejorative 'frame'. In the discussion that follows, we examine the ways in which the print media in Ireland sought to cast the anti-war movement as a peril to both the regional and the national economy, addressing each of these levels in turn.

\section{Anti-war protests and Shannon airport}

Those figures within the Irish political establishment that set out to contest the arguments of an increasingly vocal anti-war movement often sought to underline the importance of the US military to Shannon airport and to the wider regional economy of which it was, and remains, the hub. While these claims featured occasionally in the initial stages of the research that we carried out, they would become rather more numerous and insistent in the days after Mary Kelly and the Pitstop Ploughshares took direct action against the same American Navy plane parked at the facility (Browne, 2008: 99). In the wake of these incidents, many journalists were quick to reproduce official estimates of their likely cost to the Irish taxpayer. The assertion of a senior police officer that the bill for repairing the aircraft would amount to the suspiciously round figure of $€ 500,000$ remained entirely unsubstantiated throughout the period that we considered. This offered little deterrent, however, to journalists working in a range of Irish newspapers who recited the unverified statistic on no fewer than 21 separate occasions.

The coalition partners were at pains to underline that the anti-war protests would have broader economic consequences for Shannon airport that would dwarf the substantial cost to the public purse of repairing a single piece of US military hardware. In the wake of the actions carried out by Mary Kelly and the Pitstop Ploughshares, An Taoiseach Bertie Ahern was moved to dispense with his habitual evasions. The Fianna Fáil leader issued one of his most strongly worded attacks on the anti-war movement and offered perhaps his most explicit defence to date of the use of Shannon airport by the American military. Under the arresting headline 'Cabinet set to approve use of Army to guard US planes', the Irish Times in its edition of 4 February 2003 sought to communicate something of Ahern's ire:

Sharply critical of the anti-war protesters, the Taoiseach, Mr Ahern, declared: "Maybe we were a bit over-tolerant of peaceful protesters, when they are not peaceful protesters, carrying hammers, lump hammers and pick-axe handles." 
Refuelling of military and civilian aircraft provides 40 per cent of Shannon's revenues, he said.

"There is a real danger that we would lose that. That would be devastating for Shannon."

The report carried in what was still often referred to at the time as the "national paper of record' was more or less reproduced in the columns of its principal rival. On its front page on the same day, the Irish Independent observed:

In a strong reaction to the attack Mr Ahern said: "We see that maybe we have been a bit over tolerant with people protesting when they are not one bit peaceful". These people, he said, were not engaged in peaceful protest and "we cannot tolerate that".

He said that refuelling represented $40 \%$ of the business of Shannon. It was important for the area and there was a "real danger" of losing that business which would be "devastating".

These twin articles illustrate well the manner in which Irish newspapers sought to handle the economic debates that attended the Iraq crisis. In the main, journalists tended to avoid explicit endorsements of the argument that anti-war protests would visit economic ruin on Shannon and its environs. There were some examples of this version of polemic - one of which we will encounter shortly - but in general they were rare. Most journalists tended to eschew the temptation to explicitly endorse official discourse on the economics of opposing the Iraq war and opted instead to simply record time and again the views of government figures and their spokespersons. This seemingly dispassionate reportage can of course be remarkably persuasive, inviting the reader as it does to embrace as matters of fact what are in reality matters merely of opinion (Phillips et al., 2010; Reavey, 2013).

The strident economic opinions of powerful political players that were documented by a range of journalists invariably turned out, it should be acknowledged, to be strikingly at variance with the facts. A critical illustration of this would be Bertie Ahern's assertion - repeated on three separate occasions in the Irish Times alone - that refuelling represented some 40 per cent of business at Shannon. This was in effect a sleight of hand that invited the audience to draw a politically convenient inference, namely that because the American military was refuelling at Shannon it must, therefore, be the source of two fifths of turnover at the airport. The reality was, however, that the passage of US troops through the facility only provided a miniscule amount of its business. In 2002 as a whole, for instance, American military cargo represented 1.5 per cent of all flights and American troops less than 3 per cent of all passengers passing through Shannon. Journalists writing about the airport would - or at least should - have known that these were the real statistics mapping the economic profile of the airport because some of their own colleagues had reported them on several occasions previously (Evening Herald, 4 September 2002; Irish Times, 18 January 2003; Irish Independent, 21 January 2003). And yet they continued to repeat the argument emanating from the political class that the withdrawal of American troops would decimate the economy of Shannon and its entire hinterland.

This propensity among Irish journalists becomes especially apparent when we turn to consider the titles produced by the most powerful news group in Ireland. On 21 January 2003, Eugene Hogan wrote a short piece in the Irish Independent in which he repeated information already in the public domain indicating that the contribution of the US 
military in the Shannon region was vastly smaller than often claimed in official discourse. This article would appear to have evaded the attention of one of his more high profile colleagues writing on the same issue for the sister Sunday newspaper. Less than a fortnight after Hogan's article appeared, Brendan O'Connor turned his attention to a recent incident of direct action at Shannon. In one of the few examples in which a journalist broke from ostensibly straight reportage and offered an explicit enunciation of the official line on events at the airport, O'Connor informed readers of the 2 February 2003 edition of the Sunday Independent:

Mary Kelly could have cost Ireland much more than a $€ 1 \mathrm{~m}$ with last Wednesday's action. She has also jeopardised what is a huge source of legitimate income for Shannon Airport. The US Navy and Air National Guard have been flying planes through Shannon for donkey's years. They pay the same fees as anyone else, they buy lots of fuel and when there are overnight stops, as in the case of the VR 59th last Tuesday night, they provide valuable income for local hotels in the off-season.

Like it or not, without these flights, Shannon would be practically deserted for more than six months of the year.

This closing assertion was sharply at odds with the simple facts of the matter. The passage of American troops represented less than 3 per cent of the business of Shannon airport at the time and yet readers of the newspaper with the largest circulation in the country were being invited to believe that it was the US military that was responsible for keeping the place open for more than half the year. While the claims made about Shannon that were initiated by government politicians and reproduced by Irish journalists typically possessed little factual basis, this did not prevent them securing a certain purchase on the popular imagination. One of the most insistent voices during the frequently heated debates about developments at the airport was Willie O’Dea, a senior Fianna Fáil politician representing the adjoining parliamentary constituency of Limerick city. This prominent public figure would regularly invoke a frame that is often employed by those seeking to marginalise radical social movements (Gitlin, 1980). The Limerick politician contested time and again that protestors against the passage of American troops through Shannon were from elsewhere and hence unrepresentative of local opinion on the matter. O'Dea was at pains to underline a divergence between the interests of people living in that particular part of the west of Ireland and those of an anti-war movement that was based largely in Dublin. In the 8 February 2003 edition of the Irish Examiner, for instance, he was quoted as saying: 'These people protesting might not be so strident if their own jobs were on the line.' The rhetorical device employed here is a familiar part of Irish political culture and seeks to capitalise upon the sense of many people living in the regions that the cultural and political elite in metropolitan Dublin does not have their interests at heart. Opinion polls conducted at the time would suggest that this enduring strategy might well have had an impact on popular opinion. It is telling perhaps that that the only one of the four Irish provinces to record a majority in favour of the Iraq war in polls conducted before the invasion began was Munster, which includes Shannon and its environs (Irish Political Studies, 2005: 52). 
The fact that the argument that preventing the American military using Shannon airport would prove economically ruinous gained considerable ground in that particular locality was not entirely surprising of course. Rather more so perhaps was that some elements of the anti-war movement came to accept the logic, if not necessarily the conclusions, at the heart of official discourse in the period. The coalition partners had time and again insinuated that people in Ireland faced a simple, though difficult, choice between opposing the American drive to war and retaining thousands of jobs in the Shannon region. At a press conference reported in the Irish Examiner on 5 February 2003, a prominent member of Sinn Féin, one of the larger political parties opposed to the Iraq war, appeared to reproduce this essentially groundless binary. Aengus Ó Snodaigh was quoted as declaiming that 'Irish neutrality and an independent foreign policy are being exchanged for $40 \%$ of the business at Shannon Airport.' The even more sobering reality was, of course, that if Ireland had indeed traded its political independence it had done so for an altogether more trifling sum.

\section{Anti-war protests and the Celtic Tiger}

Those political forces in Ireland that were sympathetic - in principle or in practice - to the 'war on terror' contested that opposing the Bush administration would spell economic disaster not only at regional level but at national level as well. Over the first 5 months of the period covered in our research, the debate about the economic consequences of anti-war protest centred almost exclusively on the issue of Shannon airport. In the early spring of 2003, however, the locus of these exchanges began to shift towards the national context. On 6 February 2003, 3 days after the Pitstop Ploughshares' action against a US military aircraft stationed at Shannon, the first of a series of articles appeared in the Irish press in which government figures insisted that the anti-war movement was placing the entire future of the Celtic Tiger in peril. Over the next two weeks, the volume of stories concerned with events at Shannon airport declined as the focus of debate on the economics of anti-war protest moved quite explicitly towards the national level. This shift was prompted in part by the enormous demonstration that brought Dublin to a standstill on 15 February 2003. In the flurry of 'economic' stories that appeared in the week that followed that dramatic illustration of popular opposition in Ireland to the looming invasion of Iraq, there was only one specifically concerned with Shannon.

In part, this transition reflected the strategic response of the state to the emergence of the anti-war movement as a potentially influential player in Irish political life. On 15 February 2003, the international day of protest against the prospective invasion of Iraq saw more than 100,000 people march against the war in Dublin (Miller, 2005: 170). The scale of the demonstration caught most political commentators - not to mention the organisers themselves - completely by surprise and gave the clearest indication thus far of the breadth of support for the anti-war movement among the Irish public (Little, 2004: 47). Mindful of the need to avoid alienating such a large swathe of the electorate, Bertie Ahern confirmed his status as an astute politician when he commented that he was 'pleased' that so many Irish people had turned out, demonstrating, he claimed, that they shared his commitment to a peaceful resolution of the Iraq crisis. These platitudes signalled the existence of a very brief period of grace before the 
political establishment began what appeared to be an intentional campaign to undermine the anti-war movement.

The harbingers of this explicit ideological assault were, inevitably, the avowedly proWashington figures at the helm of the Progressive Democrats. On 21 February 2003, the PD leader and Tánaiste (Deputy Prime Minister) Mary Harney issued a caustic attack on those opposed to the 'war on terror' in a speech that included the first of what would become many allegations that peace protestors were motivated merely by the basest forms of 'anti-Americanism'. ${ }^{3}$ This address to a party meeting in Limerick would signal the beginning of a series of statements in which establishment figures sought to tarnish the credibility of an anti-war movement that was at the peak of its powers. One of the central concerns of these pronouncements focused upon the potential economic consequences were Ireland to fail to accommodate the interests of an American administration evidently committed to going to war against Iraq.

The discourse of those within government circles who sought to discredit the antiwar movement invariably engaged a simple, though often effective, rhetorical device. In speeches and statements, politicians would set out what were offered as two incontrovertible propositions: firstly, that the United States had played an indispensible part in Ireland's remarkable economic renaissance and, secondly, that the United States would expect the full support of Ireland at this critical time of war. On most occasions, these statements were simply allowed to nestle beside one another without an explicit or causal link being drawn between them. The audience was simply invited to draw their own conclusions from a rhetorical association that clearly suggested that the existing field of political possibility offered a simple choice between continued prosperity and adherence to an ideal of political neutrality that was already compromised. What were offered as mere dispassionate statements of fact were easily rendered into the loaded rhetorical question that dominated Irish political discourse as the Iraq war loomed: 'Would you trade your new found wealth for a political independence that may not even be possible?'

The response of Irish newspapers to this particular strain of official discourse broadly echoed the manner in which they had responded to the claims about Shannon airport emanating from government circles only a few weeks earlier. There were, predictably, a few occasions on which journalists dispensed with their habitual claim to objectivity by making explicit and then endorsing the contention insinuated within the statements of the political establishment in this period. A case in point was an article in the 18 February 2003 edition of the Irish Independent, which featured in the 'news' section but bore all the hallmarks of an 'op-ed' piece. Three days after the anti-war movement had brought Dublin to a standstill, Sam Smyth gave voice to a claim that was increasingly prevalent but still mainly implicit within official discourse, namely that if Ireland were to snub the political wishes of Washington the economic consequences might be very grave indeed. In an article entitled 'Anti-war fervour could stymie our hi-tech industry', Smyth made the following observations:

There are 580 US companies employing 90,000 people and investing $€ 33$ bn here, that's one fifth of the workforce and 70pc of all foreign investment - and US companies exports are worth more than $€ 26 \mathrm{bn}$. Some 100,000 people are employed in the hi-tech and technology industry in 
the Republic. Making the export of technology and components subject to anti-war sensitivities can do inestimable damage to the hi-tech industry that has made Ireland the envy of Europe.

Polemics of this kind would, however, prove to be rare. There were in fact only three specific occasions when 'news' stories dealing with the political economy of opposing the invasion of Iraq strayed explicitly into the realm of the 'op-ed' piece. On the whole, journalists contented themselves with recording time and again and without comment the assertions of the political class that anti-war sentiment would bring economic ruin upon Ireland. At this point, we will provide three illustrations to give a flavour of the kinds of stories that became increasingly prevalent in the Irish press in the frenetic weeks that preceded the invasion of Iraq. The first article appeared in The Sunday Times the day after the enormous demonstration in Dublin on 'F15' and suggests that an Irish government that was all the while expressing its hopes for a peaceful resolution of the Iraq crisis had already, some 5 weeks before hostilities began, decided to side with the aggressors:

A senior government source said it was still likely Ireland would back America in a war with Iraq even without a mandate from the security council. He pointed to Ireland's economic ties to America as one of the key factors contributing to policy on Iraq. The Irish government is currently in talks to attract up to six American firms to Ireland. Talks with one company are advanced, and an announcement could be made as early as next week, according to official sources.

The instrumentalist considerations aired here were echoed in a piece in the Irish Independent on the following weekend, 22 February 2003. In an article the headline of which speculated on 'How 100,000 people turned Bertie [Ahern] into a dove', Brian Dowling pondered the likely impact of the recent vast demonstration in Dublin on the field of political possibility in Ireland:

There are critical national interests at stake. One Government source described it as follows: 'our biggest trading market is directly across the Atlantic, our second biggest market is across the Irish Sea, but our future lies in Europe.' It sums up the dilemma neatly, yet even this is not the full story. IDA Ireland reckons the government foreign policy on Iraq, whatever it is, will not affect US investment. There are, however, 592 American companies in Ireland, investing over $€ 40$ billion. It cannot be totally ignored.

In its edition the following day, The Sunday Times underlined further the economic interests strongly influencing the approach that the Irish political establishment was taking towards the Iraq crisis. Journalist Stephen O'Brien incorporated comments from the two most senior members of the government of the day:

The taoiseach outlined the kind of national interest considerations that had traditionally had an impact on our foreign policy: "There are 591 American companies in this country and total American investment in Ireland stands at over Euro 40 billion."

Mary Harney, the tanaiste, returned to the "national interest" theme at a PD lunch on Friday. "We are a European member state. We are an open trading country. Britain and America are among our closest friends. Let's keep it that way," she said. 
The three articles cited above reflect the broad tendency of Irish journalists in this period to report without challenge the frequent pronouncements of the political establishment on the likely economic consequences of widespread opposition to the Iraq war. The continual absence of any counterpoints to the views being reported did rather give the impression that the official discourse recounted in the national press represented thoroughly objective observations premised upon a balanced summary of the available data. At a time when alternative sources of information remained relatively limited, readers of Ireland's mainstream newspapers could have been forgiven for believing that if the US military were refused access to Shannon airport, the outcome would have been swift retribution in the guise of the disinvestment of American multinational capital. There was, however, never any real prospect of such an eventuality.

The US companies that established or expanded branch plants in the era of the Celtic Tiger were motivated by a simple and self-evident instrumental imperative. The unusually low rate of corporation tax in Ireland created the conditions for multinationals operating in the country to register rates of profit far in excess of their undertakings elsewhere (Allen and O'Boyle, 2013: 85). In 1998, for instance, a single Coca Cola branch plant in the County Louth town of Drogheda employing 200 people somehow managed to turn a profit equivalent to $€ 500$ million (Coulter, 2003a: 19). It would seem reasonable to suggest that these almost unparalleled fortunes weighed rather more heavily on the calculations of senior executives of American corporations in Ireland than any patriotic impulses engaged by debates about the presence of the US military at a small civilian airport in the west of the country. There was, in short, every reason to believe that American multinationals would, regardless of what happened at Shannon, simply continue to record vast profits at their Irish subsidiaries and 'no credible evidence' (Little, 2004: 227) that they might do otherwise. Nevertheless, the national press in Ireland persisted in publishing story after story initiated by establishment politicians and 'official sources' insisting that obstructing the United States in its drive to war would court economic catastrophe.

Almost none of these articles rehearsing the official line of the war, predictably, offered any balance in the form of a counterpoint from the anti-war movement (Gitlin, 1980: 188). In fact, there were only two fleeting occasions - both in the Irish Times (7 February 2003, 19 February 2003) - on which opponents of the Iraq war were given the opportunity to challenge briefly the recurrent association of a 'neutral' foreign policy and economic penury. Perhaps the voice that most convincingly challenged the government line in this respect was that, ironically, of someone from within official circles. In a significant article, The Irish Independent quoted Sean Dorgan - head of the Industrial Development Agency, the state body charged with attracting multinational corporations - who insisted that the controversies over the Iraq war would effect 'absolutely no change' in the level of foreign direct investment located in Ireland. This assertion was the first of its type to emerge from establishment circles and had, in principle, the potential to make a real impact on political debate in Ireland. The timing of their appearance, however, ensured that the IDA chief's comments had little chance of being noticed at all. The relevant article in the Irish Independent was published on 20 March 2003, the same day that the war began. As tens of thousands of American troops who had only recently passed through a small and supposedly civilian Irish airport launched the invasion of Iraq, Sean Dorgan's matter of fact demolition of one of the central arguments used to 
undermine Irish opposition to the war was consigned to the anonymity of a tiny article tucked away against the inner fold of page 12 of that day's historic edition.

\section{Conclusion}

Simon Cottle (2008) has argued that analysing coverage of protest movements in recent years reveals 'variable, shifting and sometimes more progressive alignments of the news media's reporting of demonstrations and protests than in the past'. The validity of this observation was, in broad terms, borne out by the research we conducted on press coverage of the anti-war movement in Ireland. The representations of anti-war protestors in the Irish national press often varied a great deal between newspapers and over time. As we will illustrate in other publications arising from this research project, the newspapers that dominate the market in Ireland often seemed keen to criticise or sideline anti-war groups. There were, however, times when at least elements of the Irish press corps appeared positively sympathetic to the movement. In particular, most of the Irish press - with the notable exception of the titles in the Independent group chose to depict the 15 February 2003 demonstration in a positively glowing light. While journalists were often varied and occasionally positive in their coverage of the anti-war movement, these attributes disappeared more or less completely once they were prompted to consider the 'economic consequences' of protesting against the Iraq war. In the main, Irish newspapers were content simply to record and repeat the official line that anti-war protestors represented a grave and reckless threat to the economic health of the nation.

The substance and sheer homogeneity of Irish newspapers' response to the 'economic issues' prevalent within the wider debate on Iraq might be said to have a rather broader political significance in that they illuminate the very specific topography of power that characterises contemporary Irish society. The pathway to development that Ireland had come to follow as the Cold War drew to a close articulated above all the interests of a powerful network of players located within and without the country. Central to the success of the 'Celtic Tiger' was of course the arrival of principally American multinational corporations who employed their Irish branch plants to register astronomical profits and to launder those that had originated elsewhere (Carswell et al., 2013; Debt and Development Coalition, 2015; Mercille and Murphy, 2015). The conviction that US capital was indispensible to the 'economic miracle' unfolding as the millennium turned ensured that the Irish political class became ever more anxious to court favour in Washington. While politicians on the right of the political spectrum tended to be quite explicit in expressing their devotion to 'Boston' rather than 'Berlin', those on the centre left - as the Wikileaks revelations would subsequently attest (Kerrigan, 2011) - were often no less keen to align themselves with presumed American interests as long as it could be done behind closed doors. The media were also of course central to the constellation of interests that sought to shape the direction and frame the representation of the 'Celtic Tiger'. Irish newspapers were indispensible to the construction of the master narrative that the boom years would be endless and beneficial for all, a seemingly dispassionate account that concealed the very substantial vested interests of the print media in stoking in particular a property bubble that would in time prove utterly ruinous. ${ }^{4}$ 
It is perhaps fruitful to consider the manner in which the print media in Ireland represented the 'economic consequences' of opposing the drive to war in Iraq against this particular backdrop. Some of the issues raised by the anti-war movement posed, often inadvertently, certain critical questions that were deeply inconvenient and troubling for the specific constellation of powerful political and economic forces sketched above. The defence of neutrality advanced by peace protestors led many to question rather more critically the political dependence of Ireland on the United States and this in turn led some to question rather more critically the economic dependence that lies at the heart of that deeply asymmetrical relationship. In expressing their opposition to the Iraq war, therefore, Irish peace activists asked some fundamental questions - without perhaps even meaning to - that challenged the entire model of national development that defined the Celtic Tiger era. Viewed in this particular light, the manner in which the Irish press chose to deal with the 'economic issues' arising out of the Iraq crisis becomes rather easier to understand.

When the anti-war movement in Ireland was held to merely represent the medium for a specific version of liberal moral unease, as it was on ' $F 15$ ', it was often feted in the press. When anti-war protestors were regarded as representing a challenge to the essential political economy of the state, as they were much of the rest of the time, the response of the print media was rather less supportive. In those moments, the anti-war movement was deemed to have transgressed the boundaries of 'legitimate controversy'. The predictable response of the state and the media was to close ranks in defence of a particular, powerful set of indigenous and foreign interests, a reflex given form in their shared representation of protestors as recklessly endangering the national economy. This crucial alignment that was renewed during debates on the political economy of protesting the Iraq war tells us a great deal about the specific anatomy of political and cultural power that defined - and indeed continues to define - Ireland and elsewhere in the early 21 st century.

\section{Funding}

The authors wish to acknowledge the support of the Joseph Rowntree Charitable Trust who kindly funded the research reported in this article.

\section{Notes}

1. It is worth noting that the estimation of countries' economic performance is far from an exact science. The conventional index of GDP per capita is especially problematic in the context of small open economies in which transnational corporations are particularly prominent and it is likely that statistics such as those cited here will have overstated Ireland's 'real' level of economic activity. That qualification having been made, the scale of Ireland's economic revival during the Celtic Tiger period remains genuinely remarkable. Over the course of the boom, the work force doubled, the national debt fell to historically low levels and the traditional problem of involuntary emigration came to a halt. In view of these achievements, it was hardly surprising that Ireland was identified so frequently (and, it would transpire, so erroneously) as a role model for other relatively underdeveloped economies seeking to seize the opportunities of globalization.

2. The Irish newspaper market features several British titles, including The Sunday Times featured here. While these newspapers typically produce an Irish version, they also contain 
content originally geared to a UK audience. It might be assumed that the very specific debates that unfolded in Ireland will have been shaped in part by the rather broader controversies of the British media landscape.

3. These allegations of 'anti-Americanism' were used frequently in denunciations of the antiwar movement but with little evidence in their support. Recent analysis of statistical data from the period suggests that the citizens of Ireland were, ironically, rather more favourably disposed to the United States and its foreign policy than the residents of most other European states (Lawson and Hudson, 2015).

4. In the period of the Celtic Tiger, the property trade generated more advertising revenue for Irish newspapers than all other sources combined. The proximity of the print media in Ireland to the housing boom was illustrated most starkly in 2007 when the Irish Times paid $€ 50$ million for the property website Myhome.ie (Donovan and Murphy, 2014: 159-160).

\section{References}

Adler G and Mitelman JH (2004) Reconstituting 'common-sense' knowledge: Representations of globalization protests. International Relations 18(2): 189-211.

Allen K and Coulter C (2003) The Irish Republic, the United States and the Iraq War: A Critical Appraisal. Dublin: Irish Anti-War Movement.

Allen K and O'Boyle B (2013) Austerity Ireland: The Failure of Irish Capitalism. London: Pluto.

Badiou A (2006) Fragments of a public journal on the American war against Iraq. In: Badiou A Polemics. London: Verso, 36-61.

Barbrook R (2007) Imaginary Futures: From Thinking Machines to the Global Village. London: Pluto.

Browne H (2008) Hammered by the Irish: How the Pitstop Ploughshares Disabled a U.S. WarPlane - with Ireland's Blessing. Oakland, CA: AK Press.

Carruthers SL (2011) The Media at War, 2nd edn. Houndmills: Palgrave.

Carswell S, Lynch S and Beesley A (2013) Ireland labelled a 'tax haven' as US Senate investigates Apple's offshore strategies. The Irish Times, 22 May.

Chan JM and Lee CC (1984) The journalistic paradigm on civil protests: A case study of Hong Kong. In: Arno A, Dissanayake W (eds) The News Media in National and International Conflict. Boulder, CO: Westview, 183-202.

Cottle S (2008) Reporting demonstrations: The changing media politics of dissent. Media, Culture \& Society 30(6): 853-872.

Coulter C (2003a) The end of Irish history? In: Coulter C, Coleman S (eds) The End of Irish History? Critical Reflections on the Celtic Tiger. Manchester: Manchester University Press, $1-33$.

Coulter C (2003b) The New World order of things. Capital \& Class, Summer, 27(2): 5-13.

Coulter C (2015) Ireland under austerity: An introduction to the book. In: Coulter C, Nagle A (eds) Ireland under Austerity: Neoliberal Crisis, neoliberal solutions. Manchester: Manchester University Press, 1-43.

Debt and Development Coalition (2015) Corporate Tax Secrecy and the State: The Apple Case in Ireland, Dublin.

Devine K (2006) The myth of 'the myth of Irish neutrality': Deconstructing concepts of Irish neutrality using international relations theories. Irish Studies in International Affairs 17: $115-139$.

Dimitrova DV and Strömbäck J (2008) Foreign policy and the framing of the 2003 Iraq War in elite Swedish and US newspapers. Media, War \& Conflict 1(2): 203-220. 
Dittmer J and Parr D (2011), Mediating sovereignty: A comparative latent semantic analysis of US newspapers and conflicts in Kosovo and South Ossetia. Media, War \& Conflict 4(2): 124-141.

Donovan D and Murphy A (2013) The Fall of the Celtic Tiger: Ireland and the Euro Debt Crisis. Oxford: Oxford University Press.

Doris M (2007) The Militarisation of Ireland's Foreign and Defence Policy: A Decade of Betrayal, and the Challenge of Renewal. Dublin: Afri.

Entman RM (1993) Framing: Toward a clarification of a fractured paradigm. Journal of Communication 43(4): 51-58.

Gillan K, Pickerill J and Webster F (2008) Anti War Activism: New Media and Protest in the Information Age. Houndmills: Palgrave.

Gitlin T (1980) The Whole World Is Watching: Mass Media in the Making and Unmaking of the New Left. Berkeley: University of California Press.

Hallin D (1986) The Uncensored War: The Media and Vietnam. New York: Oxford University Press.

Halloran J, Elliott P and Murdock G (1970) Demonstration and Communication: A Case Study. Harmondsworth: Penguin.

Henwood D (2005) After the New Economy: The Binge ... and the Hangover That Won't Go Away. New York: The New Press.

Irish Political Studies (2005) Data section - Republic of Ireland. Irish Political Studies 20(1): 25-75.

Kerrigan J (2011) Gilmore hasn't a shred of credibility left. Irish Independent, 5 June.

Kuhling C and Keohane K (2007) Cosmopolitan Ireland: Globalisation and Quality of Life. London: Pluto.

Lawson CW and Hudson J (2015) 'Who is anti-American in the European Union?' Sage Open. doi: $10.1177 / 2158244015584163$.

Lee JJ (1996) Ireland's magnificent 7 per cent growth rate stuns the begrudgers. Irish Times, 4 January.

Little M (2004) Zulu Time: When Ireland Went to War. Dublin: New Island.

McLeod DM and Detenber BH (1999). Framing effects of television news coverage of social protest. Journal of Communication, Summer: 1-23.

MacSharry R and White P (2000) The Making of the Celtic Tiger: The Inside Story of Ireland's Boom Economy. Cork: Mercier Press.

Mercille J and Murphy E (2015) Deepening Neoliberalism, Austerity and Crisis: Europe's Treasure Island. Houndmills: Palgrave.

Miller D (ed.) (2004) Tell Me Lies: Propaganda and Media Distortion in the Attack on Iraq. London: Pluto.

Miller R (2005) From 11 September 2001 to the war in Iraq: Irish responses to the global 'War on Terrorism'. Irish Studies in International Affairs 16: 155-174.

Mirzoeff N (2005) Watching Babylon: The War in Iraq and Global Visual Culture. London: Routledge.

Nineham C (2013) The People v. Tony Blair: Politics, the Media and the Anti-War Movement. Winchester: Zero Books.

O'Hearn D (2003) Macroeconomic policy in the Celtic Tiger: A critical reassessment. In: Coulter C, Coleman S (eds) The End of Irish History? Critical Reflections on the Celtic Tiger. Manchester: Manchester University, 34-55.

Ó Riain S (2014) The Rise and Fall of Ireland's Celtic Tiger: Liberalism, Boom and Bust. Cambridge: Cambridge University Press. 
Phillips A, Couldry N and Freedman D (2010) An ethical deficit? Accountability, norms, and the material conditions of contemporary journalism. In: Fenton N (ed.) New Media, Old News: Journalism and Democracy in the Digital Age. London: Sage, 51-68.

Reavey M (2013) Objectivity and advocacy in journalism. Media Ethics 25(1).

Rees N (2004) Ireland's Foreign Relations in 2003. Irish Studies in International Affairs 15: 205228.

Robinson P et al. (2010) Pockets of Resistance: British News Media, War and Theory in the 2003 Invasion of Iraq. Manchester: Manchester University Press.

Seppälä T (2012) Globalizing Resistance against War: Theories of Resistance and the New AntiWar Movement. London: Routledge.

Sinclair I (2013) The Stop the War Coalition, The Socialist Workers Party and Iraq. New Left Project, 4 April.

Smith NJ (2005) Showcasing Globalisation? The Political Economy of the Irish Republic. Manchester: Manchester University Press.

Tonra B (2006) Global Citizen and European Republic: Irish Foreign Policy in Transition. Manchester: Manchester University Press.

Tumber H and Palmer J (2004) Media at War: The Iraq Crisis. London: Sage.

Tyler PE (2003) A new power in the streets. New York Times, 17 February.

White D (2011) Mary Harney was right - we are closer to Boston than Berlin. Evening Herald, 24 May.

Žižek S (2005) Iraq: The Borrowed Kettle. London: Verso.

\section{Author biographies}

Colin Coulter is Senior Lecturer in the Department of Sociology, the National University of Ireland, Maynooth. His most recent publication, co-edited with Angela Nagle, is Ireland under Austerity: Neoliberal Crisis, Neoliberal Solutions (Manchester University Press, 2015).

Harry Browne lectures in the School of Media, Dublin Institute of Technology. He is the author of The Front Man: Bono (In the Name of Power) published in 2013 by Verso.

Roddy Flynn lectures in the School of Communications, Dublin City University. He is the co-editor with Tony Tracy of John Huston: Essays on a Restless Director (McFarland, 2010).

Vanessa Hetherington holds a Master in International Relations, a degree in European Business Studies and a diploma in Journalism and Media Studies. She is currently Assistant Director in charge of Policy and International Affairs at the Irish Medical Organisation.

Gavan Titley lectures in the Department of Media Studies, the National University of Ireland, Maynooth. He is the co-author with Alana Lentin of The Crises of Multiculturalism: Racism in a Neoliberal Age (Zed Press, 2011). 


\section{Appendix A}

\section{Irish press coverage of the movement in Ireland opposed to the Iraq war: Principal themes}

At an early stage of the research, a close reading of the initial batch of newspapers revealed five broad themes running through the coverage. All of the stories that we considered were coded in terms of these themes. The themes are not themselves frames, but they allowed the researchers to discern broad trends within the data and offered guidance when conducting close qualitative analysis of the framing featured in the articles under consideration. A summary of the themes is provided below:

I.The motivations ascribed to protestors by the media. In examining the data we sought to discern the manner in which Irish newspapers sought to ascribe certain motivations to the anti-war movement. At times, journalists were complimentary towards peace protestors and at others sharply hostile. These contrasts were more apparent in strands of the research other than the one under consideration here. As the article illustrates, Irish newspapers were broadly willing to echo the government assertion that the anti-war movement represented a threat to national prosperity.

2. The language employed to describe protestors. The depiction of the anti-war movement and its motivations often entailed the use of specific, at times recurring, terms to describe it. The language employed to depict the protestors ran the full gamut from the complimentary through to the pejorative. When analysing the newspapers we focused on the language used which allowed us to build a profile of the discourses employed by antiwar activists and in particular by their opponents in the political establishment.

3. The motivations ascribed to the anti-war movement by official sources. In the press coverage of the period, government figures and others from 'official' Ireland often sought to suggest that at least some of those protesting the Iraq war had motivations that had little to do with the conflict. Protestors were, for instance, often accused of advancing other, radical political agendas. We sought to gather information on how the motivations of the anti-war movement were depicted in the national press.

4. The implications of violence associated with the anti-war movement. An important theme of the debates surrounding the anti-war movement was the allegation that some protestors had violent intentions, or that their protests would draw terrorists' attention to Shannon. This aspect of public debate came increasingly to the fore in the weeks that preceded the invasion of Iraq. When analysing the newspapers, we coded these implications of violence which allowed us toidentify a very important theme that is familiar from other contexts where popular social movements come to challenge the authority of the political establishment.

5. Economic consequences of opposing the war. As the article illustrates, the political debate that the Iraq war generated in Ireland often centred on whether opposition would have 'economic consequences'. This theme proved to be one of the more prominent and clearly discernible within the data. 


\section{Appendix B}

\section{Sample of data spreadsheet}

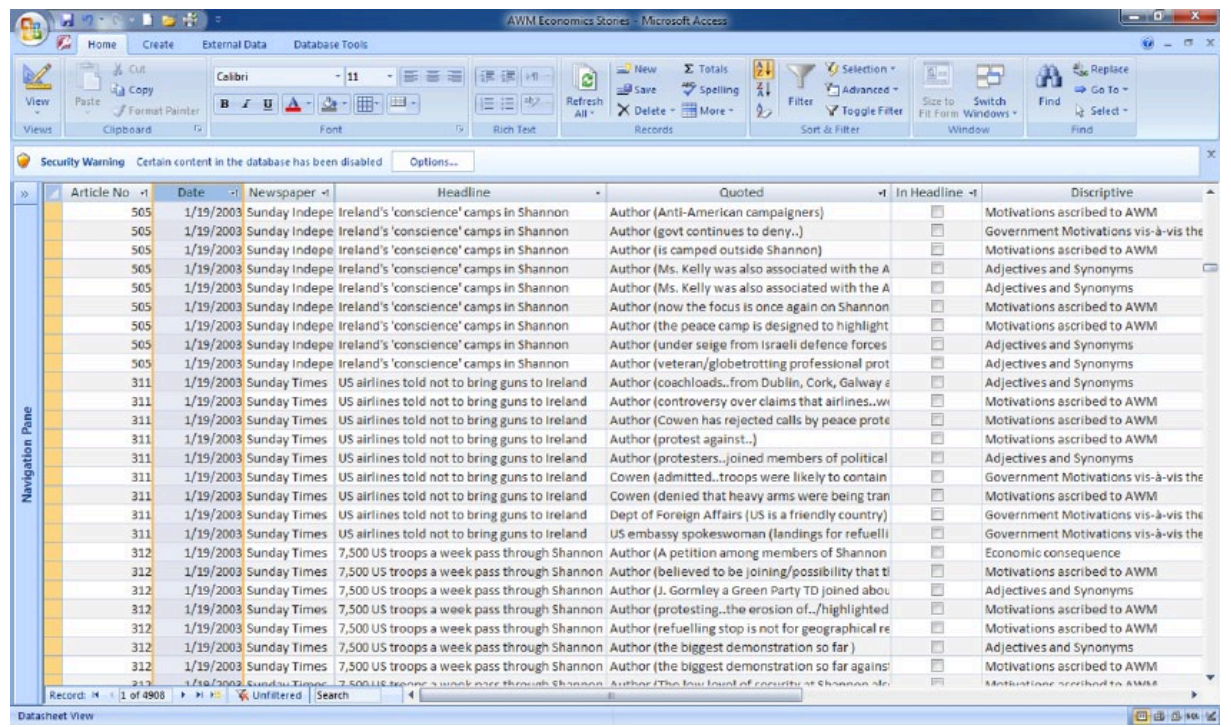

